\title{
The associations between the growth hormone/insulin-like growth factor-1 axis, adiponectin, resistin and metabolic profile in children with growth hormone deficiency before and during growth hormone treatment
}

\author{
Ewelina Witkowska-Sędek', Małgorzata Rumińska1, Anna Stelmaszczyk-Emmel2, \\ Anna Majcher ${ }^{1}$ and Beata Pyrżak ${ }^{1}$ \\ 'Department of Paediatrics and Endocrinology, Medical University of Warsaw, Warsaw, Poland; ${ }^{2}$ Department of Laboratory Diagnostics \\ and Clinical Immunology of Developmental Age, Medical University of Warsaw, Warsaw, Poland
}

This study investigated associations between the growth hormone/insulin-like growth factor-1 (GH/IGF-1) axis, adiponectin, resistin and metabolic profile in $47 \mathrm{GH}$-deficient children before and during 12 months of GH treatment. 23 short age-matched children without growth hormone deficiency (GHD) or any genetic or chronic disorders were recruited as controls at baseline. Metabolic evaluation included measurements of adiponectin, resistin, IGF-1, total cholesterol (total-C), low-density lipoprotein cholesterol (LDL-C), high-density lipoprotein cholesterol (HDL-C), triglycerides (TG), glucose, insulin, glycated haemoglobin $(\mathrm{HbA} 1 \mathrm{c})$, thyroid stimulating hormone (TSH) and free thyroxine (free T4) concentrations. The GH-deficient children had significantly higher adiponectin $(p<0.05)$ and total cholesterol $(p<0.05)$ levels, and a significantly lower level of resistin $(p<0.05)$ than the controls. Resistin at 6 months of GH treatment significantly correlated with changes in height SDS in that period $(r=0.35)$ and with the level of fasting insulin $(r=0.50)$, the HOMA-IR $(r=0.56)$ and the QUICKI $(r=-0.53)$ at 12 months of therapy. Adiponectin level at 12 months of $\mathrm{GH}$ treatment was significantly associated with changes in HDL-C within the first $6(r=0.73)$ and within $12(r=0.56)$ months of therapy, while resistin significantly correlated with an increment in IGF-1 within 12 months of treatment $(r=0.49)$ and with total-C at 12 months $(r=0.56)$. Untreated GH-deficient children had higher adiponectin and lower resistin levels than healthy short children without GHD. Adiponectin and resistin levels did not change significantly during the first 12 months of GH therapy. Good responders to $\mathrm{GH}$ treatment had a tendency for higher resistin level during GH therapy, which positively correlates with the insulin resistance parameters.

Key words: adiponectin, resistin, metabolic profile, growth hormone/insulin-like growth factor-1 axis, growth hormone deficiency, children

Received: 03 April, 2018; revised: 10 May, 2018; accepted: 10 May, 2018; available on-line: 18 June, 2018

e-mail: ewelina.witkowska-sedek@wum.edu.pl

Abbreviations: $\mathrm{GH} / \mathrm{IGF}-1$, growth hormone/insulin-like growth factor-1; GHD, growth hormone deficiency; total-C, total cholesterol; LDL-C, low-density lipoprotein cholesterol; HDL-C, high-density lipoprotein cholesterol; TG, triglycerides; $\mathrm{HbA} 1 \mathrm{c}$, glycated haemoglobin; TSH, thyroid stimulating hormone; free T4, free thyroxine; HOMA-IR, homeostasis model assessment of insulin resistance; QUICKI, quantitative insulin sensitivity check index

\section{INTRODUCTION}

Several studies have confirmed the link between the growth hormone/insulin-like growth factor-1 (GH/IGF1) axis and adipose tissue (Nilsson et al., 2005; Ciresi et al., 2007; Willemsen et al., 2007; Andersson et al., 2009; Vijayakumar et al., 2010; López-Siguero et al., 2011; Meazza et al., 2014; Orrù et al., 2017; Stawerska et al., 2017). The influence of GH on adipose tissue includes changes in its endocrine function, as well as alterations in body composition (Kuromaru et al., 1999; Sas et al., 2000; van der Sluis et al., 2002; Ciresi et al., 2016; Matusik et al., 2016; Rothermel et al., 2016). Growth hormone deficiency (GHD) leads to an increased proportion of body fat mass in relation to lean body mass, and results in a cluster of cardiometabolic risk factors (Salerno et al., 2006; Capalbo et al., 2012). GH replacement therapy exerts a number of beneficial effects on height velocity and metabolic profile, but could also lead to impairment in glucose homeostasis due to a decrease in insulin sensitivity (van der Sluis et al., 2002; Willemsen et al., 2007; Vijayakumar et al., 2010; Foster et al., 2014; Rothermel et al., 2016). Adipokines, mainly produced in adipose tissue, such as adiponectin, leptin and resistin, are involved in regulation of the short and long term energy balance, glucose and lipid metabolism and inflammatory responses, and could possibly mediate metabolic effects of the GH/IGF-1 axis (Nilsson et al., 2005; CodoñerFranch et al., 2015). On the other hand, actions of GH on adipose tissue could modify secretion of adipokines and their concentrations in the blood (López-Siguero et al., 2011; Meazza et al., 2014; Ciresi et al., 2016; Orrù et al., 2017). Adiponectin, although its mechanism of action is largely unknown, has been inversely associated with insulin resistance, obesity and the metabolic syndrome in both animal models and human studies (Scherer et al., 1995; Maeda et al., 2002; Stefan et al., 2002; Spranger et al., 2003; Reinehr et al., 2004). Reduced adiponectin concentrations in obese patients result from a chronic inflammation of adipose tissue, mediated by tumor necrosis factor- $\alpha$ (TNF- $\alpha$ ), which suppresses adiponectin expression (Orrù et al., 2017). Adiponectin also acts as a tumor suppressor factor and as an inhibitor molecule of the immune system, manifests anti-atherogenic action, and is implicated in several inflammatory responses (Wei et al., 2016; Orrù et al., 2017). In contrast to adiponectin, production and secretion of resistin seems to be inversely associated with glucose tolerance and positively associ- 
ated with obesity, insulin resistance and diabetes mellitus (Steppan et al., 2001; Silha et al., 2003; Yannakoulia et al., 2003; Zhang et al., 2003). Those associations have been well confirmed in animal models, but in humans, especially in children, they are less clear and require further investigation (Janke et al., 2002; Heilbronn et al., 2004; Codoñer-Franch et al., 2015). In human adipose tissue, in contrast to mice models, resistin is mainly expressed in the non-fat stromal-vascular fraction, consisting of macrophages, endothelial cells, and other immune cells, rather than in adipocytes, and plays an important role in inflammatory processes (Patel et al., 2003; Ronti et al., 2006; Codoñer-Franch et al., 2015). Several studies have confirmed the role of resistin in obesity-related subclinical inflammation, atherosclerosis, cardiovascular disease, non-alcoholic fatty liver disease, rheumatic disease, malignant tumors, asthma, inflammatory bowel disease and chronic kidney disease (Kaser et al., 2003; Zou et al., 2005; Fagerberg et al., 2006; Housa et al., 2006; Gualillo et al., 2007; Konrad et al., 2007; Šenolt et al., 2007; Kim et al., 2008; Filiková et al., 2009).

The aim of this study was to investigate the associations between the GH/IGF-1 axis, adiponectin, resistin and metabolic profile in children with GHD before and during $\mathrm{GH}$ replacement therapy.

\section{MATERIALS AND METHODS}

Study population and design. This was a prospective one-year follow-up study conducted at the Department of Paediatrics and Endocrinology, Medical University of Warsaw, Poland, from 2016 to 2018. The study obtained approval from the Bioethics Committee at the Medical University of Warsaw in accordance with the Declaration of Helsinki. All participants and/ or their parents gave written informed consent for participation in the study. The study included 47 children with isolated idiopathic GHD (31 boys and 16 girls) aged $4-16.58$ years (mean age $10.3 \pm 3.4$ years). The diagnosis of GHD was established according to the following criteria of the Polish therapeutic programme of GH treatment for short children with GHD (2015): height below 3th percentile for sex and age according to Polish growth charts, height velocity (HV) less than -1 SD below mean for sex- and age-matched Polish population, delay in bone age, exclusion of other causes of short stature than GHD, peak GH concentration less than $10 \mathrm{ng} / \mathrm{ml}$ in a test of spontaneous nocturnal growth hormone secretion and in two standard GHprovocative tests. Maximum growth hormone release (GH max) in a particular patient was defined as the highest concentration of $\mathrm{GH}$ in any measurement of the three tests (median $7.78 \mathrm{ng} / \mathrm{ml}$, interquartile range 5.79-8.77). Bone age was evaluated using the Greulich and Pyle method (Greulich et al., 1959). Puberty status was evaluated according to the Tanner scale (Tanner, 1962). GH was administered subcutaneously, once daily, at bedtime. Median GH dose was $0.18 \mathrm{mg} / \mathrm{kg}$ per week both in the first 6 months of GH treatment and in the whole first year of therapy. Twenty-three short children (14 boys and 9 girls) matched for age (mean age $10.5 \pm 3.6$ years; range 4.58-16.58), without GHD or any genetic or chronic disorders, were recruited from among children referred for assessment of short stature and were used as controls at baseline.

The auxological and metabolic evaluations were performed at baseline in both the GH-deficient children and in the controls, at 6 months of GH treatment in 33
GH-deficient children and at 12 months of treatment in 20 GH-deficient children. Height, weight and body mass index (BMI), calculated as weight in kilograms divided by the square of height in meters, were expressed as standard deviation scores (SDS) according to the standards of the Institute for Mother and Child, Warsaw, Poland (Palczewska et al., 2001). Height was normalized for chronological age, while weight and BMI were normalized for height-age. Baseline HV was calculated based on data from the period of 6-18 months before the initiation of therapy.

Biochemical measurements. Metabolic evaluation included measurements of fasting concentrations of adiponectin, resistin, IGF-1, total cholesterol (total-C), low-density lipoprotein cholesterol (LDL-C), high-density lipoprotein cholesterol (HDL-C), triglycerides (TG), glucose, insulin, glycated haemoglobin (HbA1c), thyroid stimulating hormone (TSH) and free thyroxine (free T4) performed at baseline and after 6 and 12 months of $\mathrm{GH}$ treatment.

Concentrations of adiponectin and resistin were measured in blood serum by enzyme immunoassay - ELISA test (Mediagnost). The lipid profile parameters (total-C, LDL-C, HDL-C, TG) were determined in blood serum using Vitros 5600 analyzer (Ortho Clinical Diagnostics). Concentrations of TSH and free T4 were measured in blood serum by immunoassay method using ARCHITECT Analyzer (Abbott Diagnostics). Concentrations of fasting glucose were determined in blood serum by glucose oxidase colorimetric method using Vitros 5600 analyzer (Ortho Clinical Diagnostics). Concentrations of $\mathrm{HbA} 1 \mathrm{c}$ were measured in whole blood by ion-exchange high-performance liquid chromatography (HPLC) using D-10 Haemoglobin Analyzer (BIO-RAD). Concentrations of fasting insulin and IGF-1 were measured in serum by immunoassay using IMMULITE 2000 Xpi Analyzer (Siemens).

The homeostasis model assessment of insulin resistance (HOMA-IR) and the quantitative insulin sensitivity check index (QUICKI) were calculated at baseline and at 6 and 12 months of GH treatment, based on the concentrations of fasting glucose $(\mathrm{mg} / \mathrm{dl})$ and fasting insulin $(\mu \mathrm{U} / \mathrm{ml})$ (Singh et al., 2010).

The HOMA-IR was calculated as follows:

HOMA-IR $=$ glucose $(\mathrm{mmol} / \mathrm{L}) \times$ insulin $(\mu \mathrm{U} / \mathrm{ml})] / 22.5$ glucose conversion factor: $\mathrm{mmol} / \mathrm{L}=\mathrm{mg} / \mathrm{dl} \times 0.05551$

The QUICKI was calculated as follows:

QUICKI $=1 /[\log$ insulin $(\mu \mathrm{U} / \mathrm{ml})+\log$ glucose $(\mathrm{mg} / \mathrm{dl})]$

Statistical analyses. The analysis of the results was performed using Statistica 13.1. Data were reported as means with standard deviation (SD) or median with interquartile ranges (IR), as appropriate. Data normality was checked by the Shapiro-Wilk normality test. The differences between the GH-deficient children and the controls at baseline were checked using the T-test for parametric data and the Mann-Whitney $U$ test for non-parametric data. Comparisons between baseline and treatment parameters in the GH-deficient children were performed using repeated measures ANOVA with Bonferroni post-hoc test for parametric data and using the Friedman test with post hoc comparisons for non-parametric data. Correlation analyses were performed using the Pearson correlation test for parametric data and the Spearman correlation analysis for non-parametric data. A $p$ value $<0.05$ was considered significant. 
Table 1. Comparison of anthropometric and biochemical parameters between the GH-deficient children and the controls at baseline

\begin{tabular}{|c|c|c|c|}
\hline Parameters & GH-deficient group & Control group & $p$ value \\
\hline Number of patients & 47 & 23 & \\
\hline Age (years) & $10.33 \pm 3.36$ & $10.47 \pm 3.61$ & ns \\
\hline Bone age (years) & $8.27 \pm 3.42$ & $9.64 \pm 3.79$ & ns \\
\hline Height SDS & $-2.57 \pm 0.56$ & $-2.57 \pm 0.57$ & ns \\
\hline Weight SDS for height-age & $-0.08 \pm 0.75$ & $-0.40 \pm 0.60$ & ns \\
\hline BMI SDS for height-age & $-0.07 \pm 1.05$ & $-0.50 \pm 0.84$ & ns \\
\hline $\mathrm{HV}(\mathrm{cm} /$ year $)$ & $5.33 \pm 1.35$ & $5.24 \pm 1.35$ & ns \\
\hline $\mathrm{IGF}-1(\mathrm{ng} / \mathrm{ml})$ & $118.00(71.10-206.00)$ & $142.50(78.60-282.00)$ & ns \\
\hline Adiponectin (ng/ml) & $17774.31(10583.66-30084.96)$ & $12518.85(10025.86-18452.35)$ & $<0.05$ \\
\hline Resistin $(\mathrm{ng} / \mathrm{ml})$ & $3.47(3.17-4.52)$ & $4.19(3.68-5.29)$ & $<0.05$ \\
\hline Total-C (mg/dl) & $169.00(159.00-184.00)$ & $153.00(142.00-177.00)$ & $<0.05$ \\
\hline $\mathrm{LDL}-\mathrm{C}(\mathrm{mg} / \mathrm{dl})$ & $93.83 \pm 22.37$ & $83.71 \pm 28.31$ & ns \\
\hline $\mathrm{HDL}-\mathrm{C}(\mathrm{mg} / \mathrm{dl})$ & $60.00(50.00-76.00)$ & $59.00(55.00-68.00)$ & ns \\
\hline $\mathrm{TG}(\mathrm{mg} / \mathrm{dl})$ & $61.00(50.00-87.00)$ & $63.00(49.00-94.00)$ & ns \\
\hline Fasting glucose $(\mathrm{mg} / \mathrm{dl})$ & $82.45 \pm 8.83$ & $79.91 \pm 7.65$ & ns \\
\hline Fasting insulin $(\mu \mathrm{lU} / \mathrm{ml})$ & $2.20(2.00-4.31)$ & $3.62(2.00-7.82)$ & ns \\
\hline HOMA-IR & $0.52(0.38-0.88)$ & $0.82(0.39-1.49)$ & $\mathrm{ns}$ \\
\hline QUICKI & $0.43(0.39-0.46)$ & $0.40(0.36-0.46)$ & ns \\
\hline $\mathrm{HbA1c}(\%)$ & $5.2 \pm 0.31$ & $5.3 \pm 0.33$ & ns \\
\hline $\mathrm{TSH}(\mu \mathrm{lU} / \mathrm{ml})$ & $1.72(1.32-2.41)$ & $1.73(1.43-2.71)$ & $\mathrm{ns}$ \\
\hline Free T4 (ng/dl) & $1.00 \pm 0.10$ & $0.98 \pm 0.12$ & ns \\
\hline
\end{tabular}

Data are presented as mean \pm standard deviation (S.D.) or median with interquartile range (IR) as appropriate; ns, not significant; GH, growth hormone; SDS, standard deviation score; BMI, body mass index; HV, height velocity; IGF-1, insulin-like growth factor-1; Total-C, total cholesterol; LDLC, low-density lipoprotein cholesterol; HDL-C, high-density lipoprotein cholesterol; TG, triglycerides; HOMA-IR, homeostasis model assessment of insulin resistance; QUICKI, quantitative insulin sensitivity check index; HbA1c, glycated haemoglobin; TSH, thyroid stimulating hormone; Free T4, free thyroxine

\section{RESULTS}

The comparison between the GH-deficient children and the controls at baseline is presented in Table 1. There were no statistically significant differences between the children with GHD and the controls in age, height SDS, weight SDS and BMI SDS normalized for height-age, and HV at baseline. The GH-deficient children had significantly higher baseline adiponectin $(\phi<0.05)$ and total-C concentrations $(p<0.05)$, and significantly lower baseline resistin concentrations $(p<0.05)$ when compared with the controls. Other biochemical parameters evaluated did not differ significantly between the GH-deficient children and the controls (Table 1). Taking into consideration the baseline pubertal status, baseline adiponectin and resistin concentrations did not differ significantly between the prepubertal and pubertal children, either in the GH-deficient children or in the controls (data not shown). In further analysis, the data were not analysed according to the baseline pubertal status in the prepubertal and pubertal patients because of the small number of children in such subgroups.

Characteristics of anthropometric and biochemical parameters in the $\mathrm{GH}$-deficient children during $\mathrm{GH}$ treatment are shown in Table 2. After the initiation of GH treatment, as expected, height SDS $(p<0.001)$ and IGF-1 concentrations $(p<0.05)$ significantly increased, as early as after the first 6 months of therapy. Weight SDS and BMI SDS normalized for height-age did not change significantly during $\mathrm{GH}$ treatment. There were no significant changes in the concentrations of adiponectin, resistin, total-C, LDL-C, HDL-C, TG, TSH and free T4 during GH treatment when compared to the baseline values. Fasting glucose concentrations significantly increased at 12 months of GH treatment $(p<0.05)$ when compared to the baseline values. Fasting insulin concentrations significantly increased as early as after the first 6 months of GH treatment $(p<0.05)$, then reached a plateau, and were still significantly higher than baseline at 12 months of treatment $(p<0.05)$. Those changes resulted in a significant increase in the HOMA-IR and a significant decrease in the QUICKI calculated at 6 months of $\mathrm{GH}$ treatment $(p<0.05$ vs. baseline values for both). HbA1c concentrations significantly increased at 6 months of GH treatment $(p<0.01)$, and then reached a plateau at 12 months of treatment $(p<0.01 v s$. baseline values).

\section{Associations between baseline adiponectin and resistin concentrations and baseline anthropometric and biochemical parameters in GH-deficient children and controls}

Baseline adiponectin and resistin concentrations were not associated with age, bone age or any of the evaluated baseline anthropometric or biochemical parameters, including $\mathrm{GH}$ deficit ( $\mathrm{GH} \max$ ), in the GH-deficient patients. In the controls, adiponectin concentrations significantly negatively correlated with weight SDS and BMI SDS normalized for height-age $(r=-0.50, p<0.05 ; r=-0.47$, $p<0.05$, respectively), baseline HV $(r=-0.43, p<0.05)$, baseline $\mathrm{HbA1c}$ concentrations $(r=-0.45, p<0.05)$ and significantly positively with baseline free T4 concentrations $(r=0.55, p<0.05)$. Baseline resistin concentrations in the controls were not significantly associated with any of the evaluated parameters.

\section{Associations between adiponectin and resistin concentrations and anthropometric and biochemical parameters in $\mathrm{GH}$-deficient children during $\mathrm{GH}$ treatment}

After the first 6 months of GH treatment, in contrast to adiponectin concentrations, resistin concentrations 
Table 2. Characteristics of anthropometric and biochemical parameters in the GH-deficient children at baseline and during GH treatment

\begin{tabular}{|c|c|c|c|c|c|}
\hline Parameters & Baseline & 6 months & 12 months & $p$ value* & $p$ value $\mathrm{e}^{* *}$ \\
\hline Number of patients & 47 & 33 & 20 & & \\
\hline Bone age (years) & $8.27 \pm 3.42$ & - & $9.78 \pm 3.40$ & & $<0.001$ \\
\hline Height SDS & $-2.57 \pm 0.56$ & $-2.22 \pm 0.59$ & $-1.94 \pm 0.65$ & - & $<0.001$ \\
\hline Weight SDS for height-age & $-0.08 \pm 0.75$ & $-0.18 \pm 0.71$ & $-0.07 \pm 0.69$ & $<0.001$ & ns \\
\hline BMI SDS for height-age & $-0.07 \pm 1.05$ & $-0.20 \pm 0.97$ & $-0.05 \pm 0.96$ & ns & ns \\
\hline $\mathrm{HV}$ (cm/year) & $5.33 \pm 1.35$ & - & $9.83 \pm 0.98$ & ns & $<0.001$ \\
\hline $\mathrm{IGF}-1(\mathrm{ng} / \mathrm{ml})$ & $118.00(71.10-206.00)$ & $209.00(161.00-365.00)$ & $287.00(202.50-358.00)$ & - & $<0.05$ \\
\hline Adiponectin (ng/ml) & $17774.31(10583.66-30084.96)$ & $21798.72(14755.84-31231.83)$ & $17571.60(9730.00-20231.52)$ & $<0.05$ & ns \\
\hline Resistin (ng/ml) & $3.47(3.17-4.52)$ & $3.70(2.98-4.43)$ & $3.60(3.01-4.16)$ & ns & ns \\
\hline Total-C (mg/dl) & $169.00(159.00-184.00)$ & $171.50(155.50-185.50)$ & $168.00(153.00-182.00)$ & ns & ns \\
\hline $\mathrm{LDL}-\mathrm{C}(\mathrm{mg} / \mathrm{dl})$ & $93.83 \pm 22.37$ & $91.27 \pm 23.74$ & $86.21 \pm 19.01$ & ns & ns \\
\hline $\mathrm{HDL}-\mathrm{C}(\mathrm{mg} / \mathrm{dl})$ & $60.00(50.00-76.00)$ & $62.00(48.50-72.50)$ & $59.00(49.00-77.00)$ & ns & ns \\
\hline $\mathrm{TG}(\mathrm{mg} / \mathrm{dl})$ & $61.00(50.00-87.00)$ & $69.00(49.00-113.00)$ & $85.00(58.00-113.00)$ & ns & ns \\
\hline Fasting glucose (mg/dl) & $82.45 \pm 8.83$ & $84.82 \pm 10.96$ & $88.00 \pm 9.12$ & ns & $<0.05$ \\
\hline Fasting insulin $(\mu \mathrm{lU} / \mathrm{ml})$ & $2.20(2.00-4.31)$ & $5.50(2.00-8.72)$ & $8.43(3.64-12.10$ & $<0.05$ & $<0.05$ \\
\hline HOMA-IR & $0.52(0.38-0.88)$ & $1.19(0.42-1.97)$ & $1.89(0.76-2.66)$ & $<0.05$ & $<0.05$ \\
\hline QUICKI & $0.43(0.39-0.46)$ & $0.37(0.35-0.45)$ & $0.35(0.33-0.40)$ & $<0.05$ & $<0.05$ \\
\hline $\mathrm{HbA1c}(\%)$ & $5.20 \pm 0.31$ & $5.30 \pm 0.28$ & $5.35 \pm 0.32$ & $<0.01$ & $<0.01$ \\
\hline $\mathrm{TSH}(\mu \mathrm{lU} / \mathrm{ml})$ & $1.72(1.32-2.41)$ & $1.84(1.39-2.30)$ & $1.81(1.22-1.96)$ & ns & ns \\
\hline Free T4 (ng/dl) & $1.00 \pm 0.10$ & $0.97 \pm 0.12$ & $0.96 \pm 0.11$ & ns & ns \\
\hline
\end{tabular}

Data are presented as mean \pm standard deviation (S.D.) or median with interquartile range (IR) as appropriate; $\mathrm{p}^{*}$ Difference between GH-deficient subjects at baseline and at 6 months of GH treatment; $\mathrm{p}^{* *}$ Difference between $\mathrm{GH}$-deficient subjects at baseline and 12 months of GH treatment; ns, not significant; GH, growth hormone; SDS, standard deviation score; BMI, body mass index; HV, height velocity; IGF-1, insulin-like growth factor-1; Total-C, total cholesterol; LDL-C, low-density lipoprotein cholesterol; HDL-C, high-density lipoprotein cholesterol; TG, triglycerides; HOMA-IR, homeostasis model assessment of insulin resistance; QUICKI, quantitative insulin sensitivity check index; HbA1c, glycated haemoglobin; TSH, thyroid stimulating hormone; Free T4, free thyroxine

significantly positively correlated $(r=0.35, p<0.05)$ with changes in the height deficit in that period ( $\Delta$ height $\mathrm{SDS}_{6 \text { months }- \text { baseline }}=$ height $\mathrm{SDS}_{6 \text { months }}-$ height $\mathrm{SDS}_{\text {baseline }}$ ). There were no significant associations between adiponectin or resistin concentrations assayed at 6 months of GH treatment and nutritional status (weight SDS or BMI SDS normalized for height-age), IGF-1 concentrations at 6 months of treatment or an increment in IGF-1 during the first 6 months $\left(\Delta\right.$ IGF- $1_{6 \text { months }- \text { baseline }}=\mathrm{IGF}-1_{6 \text { months }}$ - IGF-1 $1_{\text {baseline }}$ ) and $\mathrm{GH}$ doses administered within that period. There were also no significant correlations of adiponectin or resistin concentrations at 6 months with lipid profile parameters, glucose homeostasis parameters, TSH or free T4 concentrations assayed at 6 months of therapy. However, we found that resistin concentrations at 6 months significantly positively correlated with fasting insulin and the HOMA-IR $(r=0.50, p<0.05 ; r=0.56$, $p<0.05$, respectively) and significantly negatively correlated with the QUICKI $(r=-0.53, p<0.05)$ at 12 months of $\mathrm{GH}$ treatment.

After 12 months of GH treatment there were no significant associations between adiponectin or resistin concentrations and any of the anthropometric parameters evaluated at 12 months of therapy or an increment in height SDS $\left(\Delta\right.$ height $\operatorname{SDS}_{12 \text { months }- \text { baseline }}=$ height $\mathrm{SDS}_{12}$ months - height $\left.\mathrm{SDS}_{\text {baseline }}\right)$ or $\mathrm{HV}\left(\triangle \mathrm{HV}_{12}\right.$ months - baseline $\left.\stackrel{\text { months }}{=} \mathrm{HV}_{12 \text { months }}-\mathrm{HV}_{\text {baseline }}\right)$ in that period. At 12 months of $\mathrm{GH}$ treatment, adiponectin concentrations were significantly positively associated with changes in HDL-C concentrations ( $\Delta$ HDL-C) within the first 6 months $(r=0.73, p<0.05)$ and within 12 months $(r=0.56, p<0.05)$ of $\mathrm{GH}$ treatment, while resistin concentrations significantly positively correlated with an increment in IGF1 concentrations at 12 months of treatment $\left(\Delta \mathrm{IGF}-1_{12}\right.$ months - baseline $=I G F-1_{12 \text { months }}-$ IGF- $\left.1_{\text {baseline }}\right)$ and with total-
C concentrations $(r=0.49, p<0.05$ Fig. $1 ; r=0.56, p<0.05$, respectively).

\section{DISCUSSION}

The GH/IGF-1 axis, apart from its role in linear growth promotion, exerts a number of metabolic effects, such as the influence on carbohydrate and lipid metabolism, energy balance and body composition (Lanes et al., 2001; Møller et al., 2009; Meazza et al., 2014; Isgaard et al., 2015; Matusik et al., 2016; Rothermel et al., 2016; Berryman et al., 2017). Children with untreated GHD usually have worse metabolic panel when compared to healthy controls and suffer from increased body fat mass and de-

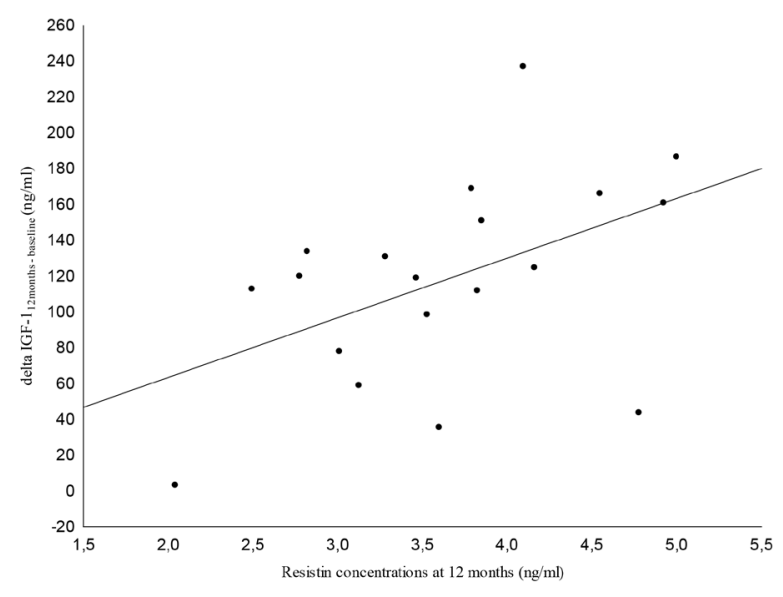

Figure 1. Correlations between resistin concentrations at 12 months of GH treatment and an increment in IGF-1 concentrations during 12 months of $\mathrm{GH}$ treatment $(r=0.49, p<0.05)$ 
creased lean body mass associated with increased peripheral inflammatory markers, osteopenia and impairment in glucose homeostasis and lipid metabolism (Salerno et al., 2006; Decker et al., 2010; Capalbo et al., 2012; Meazza et al., 2014; Ciresi et al., 2016). Adipose tissue is known as an important target for the GH/IGF-1 axis. Its endocrine function could be partially modulated by the GH/ IGF-1 axis and adipokines derived from adipose tissue possibly mediate some metabolic actions of $\mathrm{GH}$, such as the influence on energy balance and glucose and lipid metabolism (Kershaw et al., 2004; Trayhurn et al., 2006; Berryman et al., 2011; Meazza et al., 2014; Ciresi et al., 2016; Rothermel et al., 2016; Berryman et al., 2017). Several studies indicate that in patients with GHD, both children and adults, the adipokine profile could be impaired, and GH replacement therapy could be beneficial, but the reported results are discordant (Ciresi et al., 2007; Nozue et al., 2007; Andersson et al., 2009; Ciresi et al., 2016; Oświęcimska et al., 2017; Stawerska et al., 2017). Concentrations of adiponectin seem to be unaffected in children with untreated GHD (Ciresi et al., 2016). GH replacement therapy leads to increased adiponectin concentrations in some patients (López-Siguero et al., 2011), while in other patients adiponectin concentrations are unchanged or only slightly modified (Ciresi et al., 2007). Resistin concentrations in untreated GH-deficient children are usually higher than in healthy controls, but the effects of $\mathrm{GH}$ treatment on resistin concentrations are divergent (Nozue et al., 2007; Meazza et al., 2014; Ciresi et al., 2016; Stawerska et al., 2017).

Our results showed that the GH-deficient children had higher baseline adiponectin and lower baseline resistin concentrations than healthy short children without GHD or any genetic or chronic disorders, who were included as controls. Those differences were significant despite a tendency in the GH-deficient children for higher weight SDS and BMI SDS normalized for height-age than in the controls. Taking into consideration the baseline pubertal status, we did not find any significant differences in the baseline adiponectin and resistin concentrations in the prepubertal and pubertal children, either in the GH-deficient children or in the controls. In further analysis, the data were not evaluated according to the baseline pubertal status in the prepubertal and pubertal patients because of the small number of children in such subgroups. In our opinion, this is a limitation of our study, especially due to the fact that, to the best of our knowledge, the number of studies examining adipokine profile in prepubertal vs. pubertal GH-deficient children is very small, and most authors only report results in prepubertal children. We did not find any correlations of the baseline adiponectin and resistin concentrations with age, bone age or any of the evaluated baseline anthropometric or metabolic parameters in children with GHD. In contrast to those observations, in the controls adiponectin concentrations correlated, as expected, significantly negatively with nutritional status, but also with baseline HV and baseline HbA1c concentrations, and significantly positively correlated with baseline free T4 concentrations.

The discrepancy in the results of different studies evaluating the adipokine profile in untreated patients with GHD could be a result of varied metabolic panel reported in those children by several authors, who indicate that not all children with GHD have an impaired metabolic profile (Gleeson et al., 2007; LópezSiguero et al., 2011; Meazza et al., 2014; Ciresi et al., 2016; Stawerska et al., 2017). Data concerning chang- es in the lipid profile, glucose homeostasis and thyroid function were also divergent (van der Sluis et al., 2002; Andersson et al., 2009; Smyczyńska et al., 2010; López-Siguero et al., 2011; Ciresi et al., 2016; Giavoli et al., 2017; Oświęcimska et al., 2017; Stawerska et al., 2017). The study by Stawerska et al. (2017) confirmed that the baseline metabolic profile in GH-deficient children was not homogenous, and was better in GHdeficient children with low IGF-1 bioavailability expressed as the insulin-like growth factor-1/insulin-like growth factor binding protein-3 (IGF-1/IGFBP-3) molar ratio. In that group of children, weight, insulin and triglyceride concentrations were significantly lower, and ghrelin and adiponectin concentrations were significantly higher than in GH-deficient children with higher IGF-1/IGFBP-3. The authors suggest that a better metabolic profile in the group of $\mathrm{GH}$ deficient children with low IGF-1 bioavailability may be the result of the influence of high adiponectin and ghrelin concentrations on adipose tissue, glucose uptake and the orexigenic axis. They also found that, in comparison with a control group consisting of healthy children with normal height and weight, GH-deficient children before the initiation of GH therapy had similar adiponectin concentrations, significantly higher TG and significantly lower resistin concentrations (Stawerska et al., 2017). On the other hand, an earlier study by López-Siguero and coworkers (López-Siguero et al. 2011) reported that children with GHD had significantly higher baseline adiponectin concentrations than healthy, normal height, age- and sex-matched controls, but in linear regression analysis after the elimination of the influence of BMI SDS this difference disappeared. The authors also found that serum resistin concentrations were similar in GH-deficient children and in the controls. After the initiation of $\mathrm{GH}$ treatment they observed that in GH-deficient children adiponectin concentrations did not change significantly within the first 12 months of treatment, while resistin concentrations significantly decreased at 6 months of treatment, but then increased and did not differ significantly from baseline values at 12 months of $\mathrm{GH}$ therapy (López-Siguero et al., 2011).

In our prospective, one-year follow-up study, after the initiation of $\mathrm{GH}$ treatment, we did not observe any significant changes in serum concentrations of adiponectin or resistin, in lipid profile and thyroid function parameters, but there was a significant increase in fasting glucose and insulin concentrations, with a concomitant increase in HbA1c and the HOMA-IR, and a decrease in the QUICKI. We found a positive association between resistin concentrations at 6 months of therapy and an increase in height SDS within that period. Simultaneously, we noticed that resistin concentrations at 6 months significantly positively correlated with fasting insulin and the HOMA-IR and, as expected, negatively correlated with the QUICKI at 12 months of therapy. After the first 12 months of $\mathrm{GH}$ treatment, resistin concentrations significantly positively correlated with an increment in IGF-1 within 12 months of therapy and with total-C concentrations. Our observations indicate that although adiponectin and resistin concentrations did not change significantly during the first 12 months of GH treatment, good responders to $\mathrm{GH}$ therapy were at a higher risk of disturbed metabolic profile, especially impaired carbohydrate metabolism, which could lead to insulin resistance. 
Ciresi and coworkers (Ciresi at al., 2016), who evaluated one-year effects of $\mathrm{GH}$ treatment on selected adipokines, such as resistin, visfatin, leptin and omentin, and on lipid profile and glucose metabolism, reported that at baseline there were no significant differences in metabolic parameters between the GHdeficient children and the healthy short age-, sex- and BMI-matched controls, except for higher resistin and LDL-C concentrations and lower visfatin concentrations in the GH-deficient children. They also found that at baseline, resistin concentrations correlated with BMI and LDL-C in the GH-deficient children. Baseline adiponectin concentrations were positively associated with the ISI Matsuda and the QUICKI, and negatively correlated with fasting insulin and the HOMAIR, but those correlations were not confirmed in a multivariate analysis. After the first 12 months of $\mathrm{GH}$ treatment in the GH-deficient children, adiponectin and resistin concentrations did not differ significantly from baseline values, in contrast to the QUICKI values and leptin and LDL-C concentrations, which decreased significantly, and the HOMA-IR, visfatin and fasting insulin concentrations, which increased significantly at 12 months of treatment. Non-significant correlations with metabolic parameters were found for adiponectin and resistin concentrations at 12 months of GH treatment (Ciresi et al., 2016). In contrast to the above-mentioned, long-term studies, Nozue and coworkers (Nozue et al., 2007) investigated the effects of one-month $\mathrm{GH}$ treatment on serum resistin and free fatty acids (FFA) concentrations in children with GHD, and found that resistin concentrations significantly increased after that period, whereas serum FFA concentrations did not change significantly. Also, the authors did not observe any significant changes in BMI, TG, total-C, fasting glucose and $\mathrm{HbA} 1 \mathrm{c}$ levels and leukocyte counts. The authors conclude that elevation in resistin concentrations observed after 1 month of GH treatment was not associated with the $\mathrm{GH}$-induced lipolysis, and suggest that it might be partly explained by production of leukocyte-derived cytokines (Nozue et al., 2007). On the other hand, Andersson and coworkers (Andersson et al., 2009), who investigated short- and long-term effects of GH treatment on adiponectin concentrations in children with GHD, found that adiponectin levels decreased significantly after 1 week, 3 months and 12 months of therapy, and that the decreases in adiponectin concentrations after 3 months and 12 months were associated with the first-year growth response to $\mathrm{GH}$ treatment and no correlations between adiponectin and insulin levels or insulin resistance were found (Andersson et al., 2009).

The above-mentioned studies, as well as our results reported in this paper, confirm mutual dependencies between the GH/IGF-1 axis and the endocrine function of adipose tissue, but simultaneously indicate that the mechanisms of those associations are not clear. Further longitudinal investigations, involving large cohorts, are needed to establish the exact mechanisms of the influence of the GH/IGF-1 axis on adipokine profile, which may differ in short-time and long-time observations. The baseline metabolic profile, including adipokine profile, differs in children with GHD. During GH replacement therapy, some associations between the GH/IGF-1 axis, selected adipokines, lipid parameters, and carbohydrate metabolism parameters in particular, could be observed. Good responders to $\mathrm{GH}$ replacement therapy seem to have a tendency for higher resistin concentrations during GH treatment, which positively correlates with insulin resistance parameters, such as fasting insulin and the HOMA-IR. Better knowledge of those mechanisms could help to use the changes in the adipokine profile after the initiation of GH treatment to select GH-deficient patients who are at a higher risk of disturbed metabolism during GH replacement therapy. The influence of pubertal status should also be taken into consideration, but knowledge of the effect of puberty on mutual associations between $\mathrm{GH} / \mathrm{IGF}-1$ axis and adipokine profile is very limited.

\section{Conflict of Interest}

The authors declare no conflict of interest in relation to this manuscript

\section{REFERENCES}

Andersson B, Carlsson LMS, Carlsson B, Albertsson-Wikland K, Bjarnason R; Swedish Study Group for Growth Hormone Treatment (2009) Decrease in adiponectin levels correlates to growth response in growth hormone-treated children. Horm Res 71: 213-218. http:// dx.doi.org/10.1159/000201110

Berryman DE, List EO, Sackmann-Sala L, Lubbers E, Munn R, Kopchick JJ (2011) Growth hormone and adipose tissue: beyond the adipocyte. Growth Horm IGF Res 21: 113-123. http://dx.doi. org/10.1016/j.ghir.2011.03.002

Berryman DE, List EO (2017) Growth hormone's effect on adipose tissue: quality versus quantity. Int J Mol Sci 18: 1621. http://dx.doi. org/10.3390/ijms18081621

Capalbo D, Esposito A, Di Mase R, Barbieri F, Parenti G, Vajro P, Pignata C, Salerno M (2012) Update on early cardiovascular and metabolic risk factors in children and adolescents affected with growth hormone deficiency. Minerva Endocrinol 37: 379-389

Ciresi A, Amato MC, Criscimanna A, Mattina A, Vetro C, Galluzzo A, D’Acquisto G, Giordano C (2007) Metabolic parameters and adipokine profile during $\mathrm{GH}$ replacement therapy in children with GH deficiency. Eur J Endocrinol 156: 353-360. http://dx.doi. org/10.1530/eje.1.02343

Ciresi A, Pizzolanti G, Leotta M, Guarnotta V, Teresi G, Giordano C (2016) Resistin, visfatin, leptin and omentin are differently related to hormonal and metabolic parameters in growth hormonedeficient children. J Endocrinol Invest 39: 1023-1030. http://dx.doi. org/10.1007/s40618-016-0475-z

Codoñer-Franch P, Alonso-Iglesias E (2015) Resistin: insulin resistance to malignancy. Clin Chim Acta 438: 46-54. http://dx.doi. org/10.1016/j.cca.2014.07.043

Decker R, Albertsson-Wikland K, Kriström B, Nierop AF, Gustafsson J, Bosaeus I, Fors H, Hochberg Z, Dahlgren J (2010) Metabolic outcome of $\mathrm{GH}$ treatment in prepubertal short children with and without classical GH deficiency. Clin Endocrinol (Oxf) 73: 346-354. http://dx.doi.org/10.1111/j.1365-2265.2010.03812.x

Fagerberg B, Fagerlund C, Hulthe J (2006) Resistin and GFR. Kidney Int 70: 1371. http://dx.doi.org/10.1038/sj.ki.5001583

Filková M, Haluzík M, Gay S, Senolt L (2009) The role of resistin as a regulator of inflammation: implications for various human pathologies. Clinical Immunology 133: 157-170. http://dx.doi.org/10.1016/j. clim.2009.07.013

Foster C, Burton A, Scholl J, Scott ML, Gunter V, McCormick K (2014): Lipid patterns in treated growth hormone deficient children vs. short stature controls. J Pediatr Endocrinol Metab 27: 909-914. http://dx.doi.org/10.1515/jpem-2013-0488

Giavoli C, Profka E, Rodari G, Lania A, Beck-Peccoz P (2017) Focus on GH deficiency and thyroid function. Best Pract Res Clin Endocrinol Metab 31: 71-78. http://dx.doi.org/10.1016/j.beem.2017.02.003

Gleeson H, Barreto ES, Salvatori R, Costa L, Oliveira CR, Pereira RM, Clayton P, Aguiar-Oliveira MH (2007) Metabolic effects of growth hormone $(\mathrm{GH})$ replacement in children and adolescents with severe isolated GH deficiency due to a GHRH receptor mutation. Clin Endocrinol (Oxf) 66: 466-474. http://dx.doi.org/10.1111/ j.1365-2265.2007.02753.x

Greulich WW, Pyle SI: Radiographic atlas of skeletal development of the hand and wrist, ed 2. Stanford University Press. Stanford, California, 1969.

Gualillo O, González-Juanatey JR, Lago F (2007) The emerging role of adipokines as mediators of cardiovascular function: physiologic and clinical perspectives. Trends Cardiovasc Med 17: 275-283. http:// dx.doi.org/10.1016/j.tcm.2007.09.005 
Heilbronn LK, Rood J, Janderova L, Albu JB, Kelley DE, Ravussin E, Smith SR (2004): Relationship between serum resistin concentrations and insulin resistance in nonobese, obese, and obese diabetic subjects. J Clin Endocrinol Metab 89: 1844-1848. http://dx.doi. org/10.1210/jc.2003-031410

Housa D, Housová J, Vernerová Z, Haluzík M (2006) Adipocytokines and cancer. Physiol Res 55: 233-244

Janke J, Engeli S, Gorzelniak K, Luft FC, Sharma AM (2002) Resistin gene expression in human adipocytes is not related to insulin resistance. Obes Res 10: 1-5. http://dx.doi.org/10.1038/oby.2002.1

Isgaard J, Arcopinto M, Karason K, Cittadini A (2015) GH and the cardiovascular system: an update on a topic at heart. Endocrine 48: 25-35. http://dx.doi.org/10.1007/s12020-014-0327-6

Kaser S, Kaser A, Sandhofer A, Ebenbichler CF, Tilg H, Patsch JR (2003) Resistin messenger-RNA expression is increased by proinflammatory cytokines in vitro. Biochem Biophys Res Commun 309: 286290. http://dx.doi.org/10.1016/j.bbrc.2003.07.003

Kershaw EE, Flier JS (2004) Adipose tissue as an endocrine organ. J Clin Endocrinol Metab 89: 2548-2556. http://dx.doi.org/10.1210/ jc.2004-0395

Kim KW, Shin YH, Lee KE, Kim ES, Sohn MH, Kim KE (2008) Relationship between adipokines and manifestation of childhood asthma. Pediatr Allergy Immunol 19: 535-540. http://dx.doi.org/10.1111/ j.1399-3038.2007.00690.x

Konrad A, Lehrke M, Schachinger V, Seibold F, Stark R, Ochsenkühn T, Parhofer KG, Göke B, Broedl UC (2007) Resistin is an inflammatory marker of inflammatory bowel disease in humans. Eur J Gastroenterol Hepatol 19: 1070-1074. http://dx.doi.org/10.1097/ MEG.0b013e3282f16251

Kuromaru R, Kohno H, Ueyama N, Hassan HM, Honda S, Hara T (1999) Long-term effect of growth hormone (GH) treatment on body composition in children with GH deficiency. Endocr J 46 (Suppl): S35-S38

Lanes R, Gunczler P, Lopez E, Esaa S, Villaroel O, Revel-Chion R (2001) Cardiac mass and function, carotid artery intima-media thickness and lipoprotein levels in growth hormone-deficient adolescents. J Clin Endocrinol Metab 86: 1061-1065. http://dx.doi.org/10.1210/ jcem.86.3.7268

Leczenie niskorosłych dzieci z somatropinowa niedoczynnościa przysadki (ICD10 E23) hormonem wzrostu. Obwieszczenie Ministra Zdrowia z dnia 26 sierpnia 2015 r. w sprawie wykazu refundowanych leków, środków spożywczych specjalnego przeznaczenia żywieniowego oraz wyrobów medycznych. Dz. Urz. Min. Zdrow., 2015; 42: zał. B.19 (in Polish)

López-Siguero JP, López-Canti LF, Espino R, Caro E, FernándezGarcía JM, Gutiérrez-Macías A, Rial JM, Lechuga JL, Macías F, Martínez-Aedo MJ, Rico S, Rodríguez I, Guillén J, Arroyo FJ, Bernal S, Espigares R, Núñez M, Escribano A, Barrionuevo JL, Gentil J, Barrios V, Fernández-Nistal A, Martos-Moreno GA, Martínez V, Argente J (2011) Effect of recombinant growth hormone on leptin, adiponectin, resistin, interleukin-6, tumor necrosis factor- $\alpha$ and ghrelin levels in growth hormone-deficient children. J Endocrinol Invest 34: 300-306. http://dx.doi.org/10.3275/7169

Maeda N, Shimomura I, Kishida K, Nishizawa H, Matsuda M, Nagaretani $\mathrm{H}$, Furuyama N, Kondo $\mathrm{H}$, Takahashi M, Arita Y, Komuro R, Ouchi N, Kihara S, Tochino Y, Okutomi K, Horie M, Takeda S, Aoyama T, Funahashi T, Matsuzawa Y (2002) Diet-induced insulin resistance in mice lacking adiponectin/ACRP30. Nat Med 8: 731-737. http://dx.doi.org/10.1038/nm724

Matusik P, Klesiewicz M, Klos K, Stasiulewicz M, Barylak A, Nazarkiewicz P, Malecka-Tendera E (2016) Baseline body composition in prepubertal short stature children with severe and moderate growth hormone deficiency. Int J Endocrinol 4563721. http://dx.doi. org/10.1155/2016/4563721

Meazza C, Elsedfy HH, Pagani S, Bozzola E, El Kholy M, Bozzola M (2014) Metabolic parameters and adipokine profile in growth hormone deficient (GHD) children before and after 12-month GH treatment. Horm Metab Res 46: 219-223. http://dx.doi. org/10.1055/s-0033-1358730

Møller N, Jørgensen JO (2009) Effects of growth hormone on glucose, lipid, and protein metabolism in human subjects. Endoor Rev 30: 152-177. http://dx.doi.org/10.1210/er.2008-0027

Nozue H, Kamoda T, Matsui A (2007) Serum resistin concentrations in growth hormone-deficient children during growth hormone replacement therapy. Metabolism 56: 1514-1517. http://dx.doi. org/10.1016/j.metabol.2007.06.018

Nilsson L, Binart N, Bohlooly-Y M, Bramnert M, Egecioglu E, Kindblom J, Kelly PA, Kopchick JJ, Ormandy CJ, Ling C, Billig H (2005) Prolactin and growth hormone regulated adiponectin secretion and receptor expression in adipose tissue. Biochem Biophys Res Commun 331: 1120-1126. http://dx.doi.org/10.1016/j.bbrc.2005.04.026

Orrù S, Nigro E, Mandola A, Alfieri A, Buono P, Daniele A, Mancini A Imperlini E (2017) A functional interplay between IGF-1 and adiponectin. Int J Mol Sci 18: E2145. http://dx.doi.org/10.3390/ ijms18102145
Oświęcimska JM, Roczniak W, Roczniak RG, Malczyk Z, Chyra M, Mazur B, Ziora KT (2017) Serum adiponectin levels in adolescents and young adults with growth hormone deficiency. Neuro Endocrinol Lett 38: 107-116

Palczewska I, Niedźwiecka Z (2001) Wskaźniki rozwoju somatycznego dzieci i młodzieży warszawskiej. Med Wieku Rozwoj 5 (Suppl 1): 1-120 (in Polish)

Patel L, Buckels AC, Kinghorn IJ, Murdock PR, Holbrook JD, Plumpton C, Macphee CH, Smith SA (2003) Resistin is expressed in human macrophages and directly regulated by PPAR gamma activators. Biochem Biophys Res Commun 300: 472-476. http://dx.doi. org/10.1016/S0006-291X(02)02841-3

Reinehr T, Roth C, Menke T, Andler W (2004) Adiponectin before and after weight loss in obese children. I Clin Endocrinol Metab 89: 3790-3794. http://dx.doi.org/ 10.1210/jc.2003-031925

Ronti T, Lupattelli G, Mannarino E (2006) The endocrine function of adipose tissue: an update. Clin Endocrinol 64: 355-365. http://dx.doi. org/10.1111/j.1365-2265-2006-02474.x

Rothermel J, Reinehr T (2016) Metabolic alterations in paediatric GH deficiency. Best Pract Res Clin Endocrinol Metab 30: 757-770. http:// dx.doi.org/10.1016/j.beem.2016.11.004

Salerno M, Esposito V, Farina V, Radetti G, Umbaldo A, Capalbo D, Spinelli L, Muzzica S, Lombardi G, Colao A (2006) Improvement of cardiac performance and cardiovascular risk factors in children with $\mathrm{GH}$ deficiency after 2 years of GH replacement therapy: an observational, open, prospective, case-control study. J Clin Endocrinol Metab 91: 1288-1295. http://dx.doi.org/10.1210/jc.2005-0981

Sas T, Mulder P, Hokken-Koelega A (2000) Body composition, blood pressure, and lipid metabolism before and during long-term growth hormone $(\mathrm{GH})$ treatment in children with short stature born small for gestational age either with or without $\mathrm{GH}$ deficiency. J Clin Endocrinol Metab 85: 3786-3792. http://dx.doi.org/10.1210/ jcem.85.10.6917

Scherer PE, Williams S, Fogliano M, Baldini G, Lodish HF (1995) A novel serum protein similar to $\mathrm{C} 1 \mathrm{q}$, produced exclusively in adipocytes. J Biol Chem 270: 26746-26749. http://dx.doi.org/10.1074/ ibc. 270.45 .26746

Šenolt L, Housa D, Vernerová Z, Jirásek T, Svobodová R, Veigl D, Anderlová K, Müller-Ladner U, Pavelka K, Haluzík M (2007) Resistin in rheumatoid arthritis synovial tissue, synovial fluid and serum. Ann Rheum Dis 66: 458-463. http://dx.doi.org/10.1136/ ard.2006.054734

Silha JV, Krsek M, Skrha JV, Sucharda P, Nyomba BL, Murphy LJ (2003) Plasma resistin, adiponectin and leptin levels in lean and obese subjects: correlations with insulin resistance. Eur I Endocrinol 149: 331-335. http://dx.doi.org/10.1530/eje.0.1490331

Singh B, Saxena A (2010) Surrogate markers of insulin resistance: a review. World J Diabetes 1: 36-47. http://dx.doi.org/10.4239/wjd. v1.i2.36

Smyczyńska J, Hilczer M, Stawerska R, Lewiński A (2010) Thyroid function in children with growth hormone $(\mathrm{GH})$ deficiency during the initial phase of $\mathrm{GH}$ replacement therapy - clinical implications. Thyroid Research 3: 2. http://dx.doi.org/10.1186/1756-6614-3-2

Spranger J, Kroke A, Mohlig M, Bergmann MM, Ristow M, Boeing H, Pfeiffer AF (2003) Adiponectin and protection against type 2 diabetes mellitus. Lancet 361: 226-228. http://dx.doi.org/10.1016/ S0140-6736(03)12255-6

Stawerska R, Smyczyńska J, Hilczer M, Lewiński A (2017) Relationship between IGF-I concentration and metabolic profile in children with growth hormone deficiency: the influence of children's nutritional state as well as the ghrelin, leptin, adiponectin, and resistin serum concentrations. Int J Endocrinol 5713249. http://dx.doi. org /10.1155/2017/5713249

Stefan N, Bunt JC, Salbe AD, Funahashi T, Matsuzawa Y, Tataranni PA (2002) Plasma adiponectin concentrations in children: relationships with obesity and insulinemia. J Clin Endocrinol Metab 87: 46524656. http://dx.doi.org/10.1210/jc.2002-020694

Steppan CM, Bailey ST, Bhat S, Brown EJ, Banerjee RR, Wright CM, Patel HR, Ahima RS, Lazar MA (2001) The hormone resistin links obesity to diabetes. Nature 409: 307-312. http://dx.doi. org $/ 10.1038 / 35053000$

Tanner JM (1962) Growth at adolescence, 2 edn. Oxford, Blackwell

Trayhurn P, Bing C, Wood IS (2006) Adipose tissue and adipokinesenergy regulation from the human perspective. J Nutr 136 (Suppl 7): 1935S-1939S. http://dx.doi.org/10.1093/jn/136.7.1935S

van der Sluis IM, Boot AM, Hop WC, De Rijke YB, Krenning EP, de Muinck Keizer-Schrama SM (2002) Long-term effects of growth hormone therapy on bone mineral density, body composition, and serum lipid levels in growth hormone deficient children: a 6-year follow-up study. Horm Res 58: 207-214. http://dx.doi. org/10.1159/000066262

Vijayakumar A, Novosyadlyy R, Wu Y, Yakar S, LeRoith D (2010) Biological effects of growth hormone on carbohydrate and lipid metabolism. Growth Horm IGF Res 20: 1-7. http://dx.doi.org/10.1016/j. ghir.2009.09.002 
Wei T, Ye P, Peng X, Wu LL, Yu GY (2016) Circulating adiponectin levels in various malignancies: An updated meta-analysis of 107 studies. Oncotarget 7: 48671-48691. http://dx.doi.org/10.18632/oncotarget. 8932

Willemsen RH, van Dijk M, de Rijke YB, van Toorenenbergen AW, Mulder PG, Hokken-Koelega AC (2007) Effect of growth hormone therapy on serum adiponectin and resistin levels in short, small-for-gestational-age children and associations with cardiovascular risk parameters. J Clin Endocrinol Metab 92: 117-123. http:// dx.doi.org/10.1210/jc.2006-0852

Yannakoulia M, Yiannakouris N, Blüher S, Matalas AL, Klimis-Zacas D, Mantzoros CS (2003) Body fat mass and macronutrient intake in relation to circulating soluble leptin receptor, free leptin index, adiponectin, and resistin concentrations in healthy humans. J Clin Endocrinol Metab 88: 1730-1736. http://dx.doi.org/10.1210/jc.2002021604

Zhang JL, Qin YW, Zheng X, Qiu JL, Zou DJ (2003) Serum resistin level in essential hypertension patients with different glucose tolerance. Diabet Med 20: 828-831. http://dx.doi.org/10.1046/j.14645491.2003.01057.x

Zou CC, Liang L, Hong F, Fu JF, Zhao ZY (2005) Serum adiponectin, resistin levels and non-alcoholic fatty liver disease in obese children. Endocr J 52: 519-524. http://dx.doi.org/10.1507/endocrj.52.519 